HORN, Geraldo Balduíno; GERMINARI,

Geyso Dongley. $O$ ensino de

história e seu currículo; teoria e método. Petrópolis: Vozes, 2006.

$158 \mathrm{p}$.

\title{
Um "novo" ensino de história, logo, um "novo" currículo?
}

Com a aprovação da lei n. 10.639/ 03, mais um passo importante foi dado em direção ao oferecimento de um ensino de história renovado, no qual fosse aí incluído o ensino da cultura e da história africana e afro-brasileira. Tal medida dá continuidade aos projetos do governo federal de valorização dos diversos grupos étnicos e culturais do país, incentivando um melhor conhecimento de nossa cultura e de nossa história, iniciada com a aprovação dos Parâmetros Curriculares Nacionais Indígenas, em 2002, que contribuíram diretamente no oferecimento de um ensino fundamental específico àquelas etnias.

No entanto, se por um lado foram dados passos importantes no sentido de se adequar o ensino oferecido nas escolas públicas de ensino fundamental e médio à nossa realidade de país mestiço (tal como foi já apontado por muitos autores, como Darcy Ribeiro, no seu livro O povo brasileiro), diverso na cultura e variado etnicamente; de outro, o governo federal não tem alcançado a mesma eficiência na melhoria das condições do ensino nas escolas, valorizando e capacitando adequadamente os professores para estarem aptos a executar tais mudanças. São ainda escassos estudos e pesquisas que viabilizem aos professores das redes públicas de ensino a capacitação e o conhecimento necessários para ministrar suas disciplinas, adequando-se as medidas legais e oferendoas com as inovações necessárias. 
Nesse sentido, a publicação de livros, com ênfase nas questões teóricas e metodológicas do ensino de história, como $O$ ensino de história e seu currículo, são particularmente importantes para o melhoramento e amadurecimento de nossas propostas de ensino. Muito embora o principal objetivo da obra seja o de analisar "as mudanças ocorridas na política educacional na década de [19]80 e, com elas, o surgimento e a afirmação da pedagogia histórico-crítica, a qual, com o processo de consolidação da abertura política, tornou-se um dos fatores decisivos na revisão e reconceptualização do saber escolar como um todo, definindo, principalmente, seu papel no contexto social, político e econômico da sociedade brasileira" (p. 7), com ênfase nas relações de trabalho historicamente construídas e, portanto, não incidir diretamente sobre a forma de operacionalização e aplicação do ensino da cultura e da história indígena e africana e afro-brasileira nas escolas, o livro dá uma bela contribuição de como se trabalhar os Parâmetros Curriculares Nacionais de história em sala de aula e de como tornar o ensino mais adequado a realidade sociocultural dos alunos.

Para viabilizar tal proposta, os autores indicam que a "temática a ser examinada neste estudo pauta-se no trabalho como princípio organizador da teoria curricular de história e vê, nas relações sociais e de produção, o objeto da história, e na dialética, o método de produção de conhecimentos. Essas questões foram amplamente discutidas por Gramsci, com base em Marx, e por outros marxistas contemporâneos" (p. 8).

Os autores justificam as escolhas temáticas e teórico-metodológicas da seguinte maneira:

A importância de tomarmos o trabalho como princípio de investigação do ensino de História, parte do pressuposto epistemológico marxista de que o trabalho humano, historicamente, impulsiona o processo de formação, desenvolvimento e transformação do modo de produção da existência humana, e por conseguinte, é atividade pela qual o homem domina as forças naturais; humaniza a natureza; se humaniza, autoproduzindo-se pela atividade criadora. Assim, o homem, pelo trabalho, vai se transformando e transformando a natureza, dominando-a, descobrindo suas leis; vai acumulando experiências/vivências que se transformam em teorias, ciências e saber. [...] Embora o atual estado da arte do tema em questão aponte para avanços significativos no plano da crítica ao velho princípio educativo e de algumas propostas de reorganização do currículo, persistem ainda lacunas no entendimento do que seja tomar o trabalho como princípio organizador dos conteúdos de História, bem como da metodologia de ensino, haja vista que, onde já se implantou uma nova proposta pedagógica, a seleção de conteúdos não vem acompanhada de discussões metodológicas. (p. 10)

Para tanto, tomam por base, de um lado, a obra de Dermeval Saviani, principalmente os livros Escola e democracia e Pedagogia histórico-críti$c a$, para fundamentar sua discussão sobre a pedagogia histórico-crítica, e de outro, a produção da historiografia marxista inglesa, na qual a ênfase dada pelos autores foi sobre as obras de E. P. Thompson e Eric J. Hobsbawm, nas quais houve uma interpretação das massas, por meio da história das relações de trabalho.

Desse modo, para distribuir melhor o conteúdo da obra, dividiram-na em três capítulos. O primeiro, "Ensino de história e currículo", "apresenta um panorama das teorias críticas e a ques- tão do currículo na renovação do saber histórico escolar no contexto da década de 1980" (p. 12), enfocando as principais discussões sobre o currículo escolar e demonstrando como a história se tornou uma disciplina tecnicamente ensinável em todos os níveis do aprendizado escolar, dando ainda ênfase nos debates sobre cultura e trabalho:

Tendo estabelecido o trabalho como princípio metodológico para a compreensão da sociedade, tornase fundamental, ao lado disso, entender a noção de que a história se move devido às contradições, os antagonismos e conflitos que estão na base da sociedade e porque são fruto da ação dos próprios homens. (p. 47)

O segundo, "Abordagens metodológicas do ensino de história", "discute as metodologias do ensino de história, tais como: a construção do tempo histórico, pesquisa no ensino e o uso escolar do documento histórico" (p. 12-13). E o terceiro, "História local, arquivos familiares e o ensino", "discute a possibilidade da utilização, no ensino de História, de documentos em estado de arquivo familiar", que vão desde reuniões familiares, momentos de lazer e trabalho, armazenadas em fotografias de álbuns familiares, até os depoimentos orais (p. 13).

Nesse sentido, as atividades se relacionarão à prática de ensino do professor(a), na medida em que as fontes escolhidas se articulem aos conteúdos selecionados, segundo um recorte determinado por uma concepção de História em que todas as pessoas fazem parte do processo histórico, bem como uma concepção de documento histórico, na qual todos os vestígios - escritos, iconográficos, orais e materiais produzidos pela ação humana são considerados fontes documentais para se estudar a história. O uso escolar dos 
documentos em estado de arquivo familiar possibilitará um ensino de História compromissado com a realidade vivida pelo aluno. (p. 141)

Pode-se, evidentemente, criticar a proposta dos autores por ter chegado com pelo menos dez anos de atraso no mercado editorial, mas isso não descredencia a obra. Pode-se ainda observar que os autores não analisaram a contribuição das medidas federais mais recentes, apontadas anteriormente, até para visualizar melhor a pesquisa, o estudo e o ensino das relações de trabalho praticadas no país no passado, com o trabalho escravo do negro (e em menor proporção do índio), e, no presente, com a questão da discriminação ainda hoje praticada sobre essas etnias (e sobre a mulher), quando trabalham ou consomem. Ain- da que essas observações sejam importantes, até para apontarem lacunas que ainda persistem em nossa historiografia sobre o ensino de história e sua aplicabilidade em sala de aula, vale destacar que a obra possui o mérito de pensar o marxismo, como uma proposta metodológica adequada para o ensino de história, num momento em que o marxismo tem sido severamente criticado e descartado, muitas vezes sem a devida justificativa e comprovação. Em contrapartida, ainda com base no marxismo, os autores demonstram a necessidade de se pensar um ensino de história voltado para todo agir humano, no qual é valorizado não apenas a ação de alguns homens representantes da elite dirigente, mas também, e principalmente, o papel das massas e dos homens e das mulheres comuns que, na verdade, se aproximam mais diretamente da realidade dos alunos nas escolas, até para que se vejam como sujeitos históricos. E verem com isso que a história, embora seja uma disciplina eminentemente abstrata ao tratar dos homens e mulheres das sociedades passadas, não deixa de ser também uma disciplina próxima, por demonstrar-lhes de onde vieram e por que chegaram a ser o que são.

Diogo da Silva Roiz Mestre em história pelo Programa de PósGraduação da Universidade Estadual Paulista (UNESP), campus de Franca.

Coordenador do curso de história da Universidade Estadual de Mato Grosso do Sul, campus de Amambai. E-mail: diogosr@yahoo.com.br. 